\title{
Pesticides in Indoor Dust and Shallow Groundwater in Rural
}

\section{Egypt}

\author{
Salwa M. Abdallah*, Khaled Y. Abdel-Halim*
}

\begin{abstract}
Objective: This study was designed to examine the existence of pesticide residues in both indoor dust and consumable subsurface shallow ground water and its association with community health in an agro-ecosystem in the Nile Delta Region. Methods: Pesticide exposure via consumption of shallow groundwater and contact with indoor dust were assessed in 7 villages in the Nile Delta of Egypt. Hand-pumped water and households' dust samples were collected on a spatio-temporal monitoring basis. A total of 50 households were randomly selected and residents were interviewed using a structured questionnaire to determine pesticide usage, exposure pathways and behavioral/health risk factors. Results: Analyses revealed that the examined shallow groundwater and indoor dust samples failed to realize the respective standards of safety in most cases. Pesticide residues detected in indoor dust were more abundant than those in groundwater. Pyrethroid compounds represented the highest residues detected in indoor dust samples, where their mean levels were $4.75,2.69$, and $15.21 \mathrm{ppm}$ for permethrin, cypermethrin, and cyahalothrin respectively. DDT, $\mathrm{HCH}$ and endosulfan were also detected in many samples in mean concentrations of 10.42 , 36.01 and $33.68 \mathrm{ppb}$; respectively. As for the link between environmental contamination and community health, through our field questionnaire, the villagers stated that water-related diseases particularly diarrhea and infectious hepatitis were predominant. Conclusion: Age, living in close proximity to agricultural fields, excessive use of pesticides indoors without adequate aeration, lack of awareness and poor water quality, represented the major risk factors. More exposure/risk assessment studies related to the Egyptian setting are necessary to enhance drinking water regulations and lower the health risks of pesticide exposure.
\end{abstract}

Keywords: Farming Community, Groundwater, Indoor Dust, Pesticides.

\section{INTRODUCTION}

Pesticides are considered among the settings. Large proportions of applied main environmental threats to human pesticides are dispersed from sprayed sites health through air, soil and water as media through drift, runoff, volatilization, off of exposure particularly in agricultural gassing and other pathways. ${ }^{(1,2)}$ Therefore,

\footnotetext{
*Mammalian and Aquatic Toxicology Dept, Central Agricultural Pesticides Lab. (CAPL), Agricultural Research Center, Ministry of Agriculture, Egypt
} 
living within agricultural areas represents a high-risk probability for pesticide exposure due to excessive use of different agrochemicals, uncontrolled patterns of pesticide use, open houses near fields, indoor use and storage of treated grains as well as storing pesticide containers close to foodstuff, living areas and drinking water supplies.(3-5) In addition, pesticides may be found indoors even when there is no known use of pesticides on the property. ${ }^{(6)}$ Once indoors, a pesticide may exist in air, reside on surface or become incorporated in dust. Actually, dust inside homes is known to collect pesticide residues and carpets are considered the main storage sites of fine dust especially near entryways. ${ }^{(3,7)}$ These residues may embrace pesticides applied for home pest control, including compounds which were used years ago persisting in carpets, and those administered outdoors that are tracked into the home on shoes. Indeed, an estimated $31 \%$ of indoor dust originated from outdoor soil.(8) In addition, it was stated that tracking-in the outdoor soil was the principal source of about half of the pesticides detected in the indoor air of one's monitored home, ${ }^{(9)}$ while pesticides which remain outdoors, are generally broken down by sun, rain, and soil microbes.

Several organophosphate, carbamate pesticides and synthetic pyrethroids are registered for use in Egypt to counter several crop infestations during the growing season. Since about 25 years, the use of DDT and many other organochlorine pesticides in Egyptian agriculture has been banned. However, these long persistent compounds are still detectable in many different types of environmental samples (e.g., water, fish, sediment, vegetables, fruits, milk, foodstuffs).(10) Large number of compounds known as "extremely hazardous", "highly hazardous", "probable human carcinogenic", and "possible human carcinogenic", are listed among the 
pesticides registered and recommended for use in Egypt during the season of 2001/2002.(10) Currently, indoor use of pesticides for pest control is widespread in Egypt but accurate information concerning the types and amounts of Egyptian household pesticide use, or numbers of poisoning or contamination incidents, is unavailable. Generally, use of indoor pesticides is inadequately managed.(11) Moreover, farming communities living in agro-ecosystems of Egypt are more likely to receive additional risk of exposure to pesticides through consumption of water produced via primitive water systems and/or private wells which are often shallow and poorly protected.(12) In fact, shallow groundwater may represent the primary source of water in many rural Egyptian settings for drinking, bathing, irrigation and animal watering. Surveys carried out in our study area showed a widespread contamination of tap and subsurface water samples with residues of several organochlorine pesticides..$^{(13,14)}$

Exposure to these chemicals may result in pesticide poisoning that is either acute with effects such as dizziness, vomiting, diarrhea or chronic, including disturbance of the nervous, endocrine, or reproductive systems. Children are especially susceptible to pesticide intoxication, due to physiological differences from adults that facilitate pesticide absorption and retention, as well as their greater sensitivity to specific toxic chemicals at given concentrations. ${ }^{(15)}$

As a result of the above concerns, the current study was designed to examine the existence of pesticide residues in both indoor dust and consumable subsurface shallow ground water and its association with community health in an agroecosystem in the Nile Delta region.

\section{MATERIALS AND METHODS}

\section{Study Setting}

This is a cross-sectional study that was conducted in seven villages in Etay El- 
Baroud district, Behira Governorate. These villages were chosen as due to abundance of agricultural areas and heavy use of pesticides (Figures 1 and 2). Most of selected households were close to agricultural fields ( 1 to $20 \mathrm{~m}$ distance). Over $90 \%$ of the villagers depend on shallow groundwater as a major source of drinking and domestic purposes. Most of the pumps were installed at average of 18$24 \mathrm{~m}$ depth.

A survey questionnaire was conducted in 50 households randomly selected to gather information on characteristics of hand pumps, water quality, health problems, children's health status, field activities, pesticide usage, crop rotation, grains' storage, animal breeding, house characteristics, type of carpets, cleaning process, level of aeration and other parameters were also considered.

\section{Sampling}

Water samples were collected on a spatial-temporal monitoring basis during
2008/2009 (one year period) according to standard methods. ${ }^{(16)}$ Sampling sites covered 35 locations of hand pumps, dug at different depths with varied years of usage. Samples were obtained when the stream flow remained quite steady and water was allowed to run for at least 15 min. Two liters of water were collected and transferred in ice boxes to the laboratory for analysis. On the other hand, samples of house dust were collected from all household compartments using appropriate cleaning kits. ${ }^{(7,17)}$ The collected samples were packed in ethylene bags, labeled, transferred, and kept in deep freezer until analysis.

\section{Pesticides monitoring}

Multi-residues of pesticides in water samples were extracted using C18 SEPPAK cartridge, ${ }^{(18)}$ at a flow rate $10 \mathrm{ml} / \mathrm{min}$. For dust samples, $25 \mathrm{~g}$ were sieved (50 mesh) and residues were extracted according to standard methods. ${ }^{(19)}$ Samples were extracted by $200 \mathrm{ml}$ of $1: 1$ 
v/v $n$-hexane: acetone solution and then fractionated on florisil column using a solvent system [100 $\mathrm{ml}$ of each $6 \%, 15 \%$ and $50 \%$ of diethyl ether in petroleum ether $\left.\left(40-60{ }^{\circ} \mathrm{C}\right)\right]$. Resulting fractions were concentrated in $n$-hexane and then multiresidues of pesticides were identified by gas chromatography (GC, HP 6890 series) equipped with EC and FP detectors. Organochlorine (OCs) and pyrethroid residues were determined using HP-5MS capillary column at a carrier gas flow rate of $4 \mathrm{ml} / \mathrm{min}$, injector and detector temperatures were $280{ }^{\circ} \mathrm{C}$ and $300{ }^{\circ} \mathrm{C}$; respectively. The column temperature program was $170{ }^{\circ} \mathrm{C}$ for $2 \mathrm{~min}$, raised at rate of $5{ }^{\circ} \mathrm{C} / \mathrm{min}$ to $260{ }^{\circ} \mathrm{C}$ then held for 25 minutes. DB-17 capillary column was applied as a confirmatory procedure. Organophosphorus (OPs) residues were determined using PAS-1701 capillary column at a carrier gas flow rate of 3 $\mathrm{ml} / \mathrm{min}$ injector and detector temperatures were $280{ }^{\circ} \mathrm{C}$ and $250{ }^{\circ} \mathrm{C}$; respectively. The oven temperature program was $170{ }^{\circ} \mathrm{C}$ for 2 minutes and raised at rate of $5{ }^{\circ} \mathrm{C} / \mathrm{min}$ to $230^{\circ} \mathrm{C}$ then held for 2 minutes and raised at rate of $10^{\circ} \mathrm{C} / \mathrm{min}$ to $240{ }^{\circ} \mathrm{C}$ then held for 2 minutes. Hydrogen and air were used for combustion at 75 and $100 \mathrm{ml} / \mathrm{min}$; respectively. CP-CIL-13CB was used as a stationary phase to confirm the detection of OP pesticides.

\section{Quality assurance}

Methods and instruments were fully validated as part of a laboratory quality assurance system. ${ }^{(20)}$ The Codex committee's criteria for quality assurance were followed to determine the performance of the multi-residue method. Recovery, accuracy, limit of determination, and coefficient of variation (CV) were determined for every compound. Average recoveries were $63.5-97 \%$ in water and $58.1-78.4 \%$ in case of house dust. Reproducibility, expressed as relative standard deviation, was less than $20 \%$. The limit of determination for water and 
dust ranged from 0.01 to $0.05 \mathrm{ng} / \mathrm{ml}$ of water and $\mathrm{ng} / \mathrm{g}$ of dust sample.

\section{Data analysis}

All data were processed by Microsoft Excel (Microsoft 2000) and statistical analysis was conducted using the program of SAS Release 6.12.(21,22)

\section{RESULTS}

Environmental/health priorities as perceived by the studied community were highlighted based on the information gathered by direct interviews using structured questionnaire and one-on-one interviews. Excessive usage of pesticides and deteriorated health status were representing priority issues for the community, in general.

\section{Farmers' households:}

Characteristics of households in the studied farming community are illustrated in table 1. The data described the household areas, number of floors and rooms, age of children, number and quality of carpets or mats, level of aeration and distance between field and household.

\section{Community health status:}

In all studied villages community attitudes and practices related to drinking water, quality and its relation to health problems particularly water-related diseases were collected using one-on-one interviews using a predesigned questionnaire, and is presented in table 2. Responses for children health status were conveyed by either parent of the child. Evidently, the percentage of sick family members was relatively high among children and women, where frequency of disease prevalence among children was (36\%) followed by women (28\%), elders (21\%), and men (14\%). Respondents in villages believed that the water quality they drink was the cause of their health problems and intestinal parasitic diseases, kidney dysfunction and typhoid represented high priority diseases (46\%, $16 \%$ and $14 \%$, respectively). The way the community copes with low quality of water 
was found to be dependent on the education level.

\section{Pesticide usage:}

It was revealed that, $72 \%$ of the surveyed residents used pesticides in their homes. Spray formulations represented $70 \%$ of their usage against houseflies and mosquitoes (mostly pyrethroid compounds) for daily routine $(51 \%)$, in all rooms $(66 \%)$ or particularly in bedrooms (23\%) with no adequate aeration (57\%). Furthermore, 56\% of them used powder/granular pesticide formulations against cockroaches, bugs, ants and fleas. Twenty five percent of participants used dimethoate against animals ticks and mites. It is worth mentioning that cropping pattern differs seasonally. Wheat and clover were the main winter crops (42\%, 43\%; respectively) while corn, rice and cotton were cropped in summer $(36 \%, 31 \%$ and $27 \%$; respectively). Several types of pesticides were applied by farmers; they included chlorpyrifos-methyl, profenofos, malathion, dimethoate, pirimphos-methyl, sumithion, diazinon, prothiophos, carbofuran, methomyl, sulphur, growth regulators, fungicides and herbicides, such as benthiocarb, metribuzin, and glyphosate.

The majority of villagers (75\%) reported that within a household there is a storage place for agricultural pesticides and veterinary drugs generally located in close proximity to grains and other food stuff storage places. Most of the residents (70\%) complained about lack of awareness programs related to potential risks of pesticide usage on both environment and human health. In addition, they do not wear any protective clothing or apply other proper precautions during pesticide spraying (69\%). 
Table 1. Characteristics of households in the studied farming community $(n=50)$

\begin{tabular}{|c|c|c|}
\hline Characteristics & No. & (\%) \\
\hline \multicolumn{3}{|l|}{ Gender* } \\
\hline Male & 42 & 84 \\
\hline Female & 8 & 16 \\
\hline \multicolumn{3}{|l|}{ Number of children/household } \\
\hline 0 & 2 & 4 \\
\hline $1-3$ & 13 & 26 \\
\hline $3-6$ & 21 & 42 \\
\hline $6-8$ & 14 & 28 \\
\hline \multicolumn{3}{|l|}{ Age of children (years) } \\
\hline $0-1$ & 14 & 28 \\
\hline $1-3$ & 19 & 38 \\
\hline $3-6$ & 10 & 20 \\
\hline $6-8$ & 3 & 6 \\
\hline 8-12 & 4 & 8 \\
\hline \multicolumn{3}{|l|}{ Area of household $\left(\mathbf{m}^{2}\right)$} \\
\hline $10-100$ & 13 & 26 \\
\hline $100-200$ & 31 & 62 \\
\hline $200-300$ & 4 & 8 \\
\hline$>300$ & 2 & 4 \\
\hline \multicolumn{3}{|l|}{ Number of floors } \\
\hline one floor & 26 & 52 \\
\hline two floors & 24 & 48 \\
\hline \multicolumn{3}{|l|}{ Number of rooms/floor } \\
\hline $1-3$ & 15 & 30 \\
\hline $4-6$ & 35 & 70 \\
\hline \multicolumn{3}{|l|}{ Type of ground } \\
\hline clay/mud & 14 & 28 \\
\hline flagstone & 36 & 72 \\
\hline \multicolumn{3}{|l|}{ Number of carpets/land covering } \\
\hline 0 & 10 & 20 \\
\hline $1-3$ & 12 & 24 \\
\hline $4-7$ & 23 & 46 \\
\hline$>8$ & 5 & 10 \\
\hline \multicolumn{3}{|l|}{ Type of carpet/ land covering } \\
\hline Straw mat & 29 & 58 \\
\hline Cotton mats + straw mats & 10 & 20 \\
\hline Wool mats+ straw mats & 11 & 22 \\
\hline \multicolumn{3}{|l|}{ Sources of aeration } \\
\hline presence of windows & 50 & 100 \\
\hline using fans & 40 & 80 \\
\hline using heating device & 10 & 20 \\
\hline \multicolumn{3}{|c|}{ Distance between field \& household (meters) } \\
\hline $1-20$ & 35 & 70 \\
\hline $20-40$ & 6 & 12 \\
\hline $40-60$ & 3 & 6 \\
\hline $60-100$ & 6 & 12 \\
\hline Suffering humidity in household & 21 & 42 \\
\hline
\end{tabular}

*indicates the head of household 
Table 2. Community perception of hand pumped drinking water quality and health status

\begin{tabular}{|c|c|c|}
\hline & No. & $\%$ \\
\hline \multicolumn{3}{|l|}{ Depth of hand pump } \\
\hline $1-20$ & 37 & 74 \\
\hline $20-40$ & 10 & 20 \\
\hline $40-60$ & 3 & 6 \\
\hline \multicolumn{3}{|l|}{ Water quality } \\
\hline Turbid & 10 & 20 \\
\hline Noxious odor & 13 & 26 \\
\hline Unusual taste & 5 & 10 \\
\hline Acceptable & 22 & 44 \\
\hline \multicolumn{3}{|l|}{ Amount of daily intake (L) } \\
\hline $1-2$ & 45 & 90 \\
\hline $3-4$ & 5 & 10 \\
\hline \multicolumn{3}{|l|}{ Distance between hand pump and field $(\mathrm{m})$} \\
\hline$<20$ & 33 & 66 \\
\hline $20-100$ & 3 & 6 \\
\hline$>100$ & 14 & 28 \\
\hline Presence of agricultural drainage close to hand pumps & 31 & 62 \\
\hline Belief in causal relation between environmental problems \& health & 35 & 70 \\
\hline \multicolumn{3}{|l|}{ Sickness of family members ${ }^{a}$} \\
\hline Husband & 7 & 14 \\
\hline Wife & 14 & 28 \\
\hline Children & 18 & 36 \\
\hline Elderly & 11 & 22 \\
\hline Cases of child death & 11 & 22 \\
\hline \multicolumn{3}{|l|}{ Water-related diseases ${ }^{\star b}$} \\
\hline Diarrhea & 20 & 40 \\
\hline Typhoid & 13 & 26 \\
\hline Dysentery & 19 & 38 \\
\hline Infectious hepatitis & 20 & 40 \\
\hline Kidney dysfunction & 17 & 34 \\
\hline Helminthes & 23 & 46 \\
\hline Dermal itching & 13 & 26 \\
\hline
\end{tabular}

a Represents responses of the head of households on our designed questionnaire and one-onone interviews. No medical investigations were conducted by our research team.

*Multiple answers were reported by the interviewee.

\section{Pesticide residues:}

Data in table 3 exhibited that pesticide residues were more abundant in indoor dust samples than in shallow groundwater. As matter of fact, about $70 \%$ of the households were located within 20 meters of agricultural fields, which may be the principal cause of pesticide existence in house dust. Pyrethroid compounds represented the highest residues 
in indoor dust samples, as their levels were

4.75, 2.69, $15.21 \mathrm{ug} / \mathrm{g}(\mathrm{ppm})$ for permethrin,

cypermethrin, cyahalothrin, respectively. and endosulfan were the most detected

Likewise, organochlorines like DDT, $\mathrm{HCH}$, and

endosulfan were found in most samples at

concentrations of $10.42,36.01$, and 33.68 $\mathrm{ng} / \mathrm{g}$, respectively. As for water samples, malathion, chlorpyrifos, cypermethrin, DDT pesticides $(0.12,0.27,2.36,0.10$ and 0.05 $\mathrm{ng} / \mathrm{ml}$ (ppb), respectively) indicating shallow groundwater vulnerability.

Table 3. Concentrations of pesticides in groundwater $(\mathrm{ng} / \mathrm{ml})$ and house indoor dust $(\mathrm{ng} / \mathrm{g})$ collected from El-Behira villages

\begin{tabular}{|c|c|c|c|c|c|c|c|}
\hline Pesticide & Mean & Variance & Min. & Max. & C.V. & Skewness & SD \\
\hline \multicolumn{8}{|c|}{ Ground water(ng/ml) } \\
\hline $\mathrm{HCH}$ & ND & - & ND & ND & - & - & - \\
\hline Hept-epoxide & ND & - & ND & ND & - & - & - \\
\hline Endosulfan & 0.053 & 0.194 & 0.006 & 0.098 & 0.049 & -0.587 & 0.038 \\
\hline Endrin & ND & - & ND & ND & - & - & - \\
\hline$D D T$ & 0.096 & 0.301 & 0.001 & 0.191 & 0.061 & -0.169 & 0.090 \\
\hline Permethrin & ND & - & ND & ND & - & - & - \\
\hline Cypermethrin & 2.359 & 2.266 & 0.225 & 16.03 & 0.252 & 2.978 & 5.136 \\
\hline Cyhalothrin & ND & - & ND & ND & - & - & - \\
\hline Fenvalerate & ND & - & ND & ND & - & - & - \\
\hline Chlorpyrifos & 0.269 & 0.457 & 0.008 & 0.713 & 0.035 & 0.862 & 0.209 \\
\hline Malathion & 0.122 & 0.372 & 0.004 & 0.529 & 0.012 & 1.473 & 0.139 \\
\hline Diazinon & ND & - & ND & ND & - & & . \\
\hline Profenofos & 0.866 & 1.093 & 0.070 & 2.241 & 0.364 & 1.667 & 1.195 \\
\hline Ethoprofos & ND & - & ND & ND & - & - & - \\
\hline Fenamiphos & ND & - & ND & ND & - & . & - \\
\hline Pirimiphos-m & 0.212 & 0.220 & 0.170 & 0.254 & 0.055 & 0.00 & 0.048 \\
\hline \multicolumn{8}{|c|}{ Indoor dust (ng/g) } \\
\hline $\mathrm{HCH}$ & 36.007 & 6.738 & 1.131 & 104.590 & 1.123 & 0.968 & 45.400 \\
\hline Hept-epoxide & 6.940 & 1.743 & 4.313 & 9.572 & 0.436 & 0.000 & 3.037 \\
\hline Endosulfan & 33.677 & 6.061 & 0.400 & 119.881 & 0.303 & 1.155 & 36.731 \\
\hline Endrin & 1260.41 & 36.100 & 131.825 & 2389.042 & 9.025 & 0.000 & 1303.18 \\
\hline$D D T$ & 10.418 & 1.807 & 1.657 & 31.623 & 0.301 & -0.582 & 3.266 \\
\hline Permethrin & 4747.06 & 91.831 & 373.010 & 17382.02 & 22.958 & 1.987 & 8432.86 \\
\hline Cypermethrin & 2698.52 & 54.861 & 92.013 & 5305.005 & 13.715 & 0.000 & 3009.72 \\
\hline Cyhalothrin & 15206.85 & 57.581 & 10.294 & 123039.04 & 5.235 & 1.325 & 3315.69 \\
\hline Fenvalerate & 134.413 & 14.702 & 18.235 & 572.531 & 2.450 & 2.373 & 216.154 \\
\hline Chlorpyrifos & 32.652 & 5.621 & 2.291 & 94.412 & 0.312 & 1.868 & 31.599 \\
\hline Malathion & 177.344 & 14.223 & 1.337 & 209.553 & 0.474 & 2.712 & 202.123 \\
\hline Diazinon & 190.136 & 30.136 & 1.096 & 1583.021 & 3.348 & 1.732 & 908.182 \\
\hline Profenofos & 38.037 & 8.566 & 1.395 & 47.557 & 0.857 & 1.727 & 73.378 \\
\hline Ethoprofos & 85.317 & 7.603 & 4.452 & 272.024 & 0.845 & 0.793 & 57.798 \\
\hline Fenamiphos & 64.735 & 7.640 & 29.522 & 152.034 & 1.910 & 1.959 & 58.374 \\
\hline
\end{tabular}


ND, not detected; Min., minimum; Max., maximum. C.V., coefficient of variation; and SD, standard deviation.

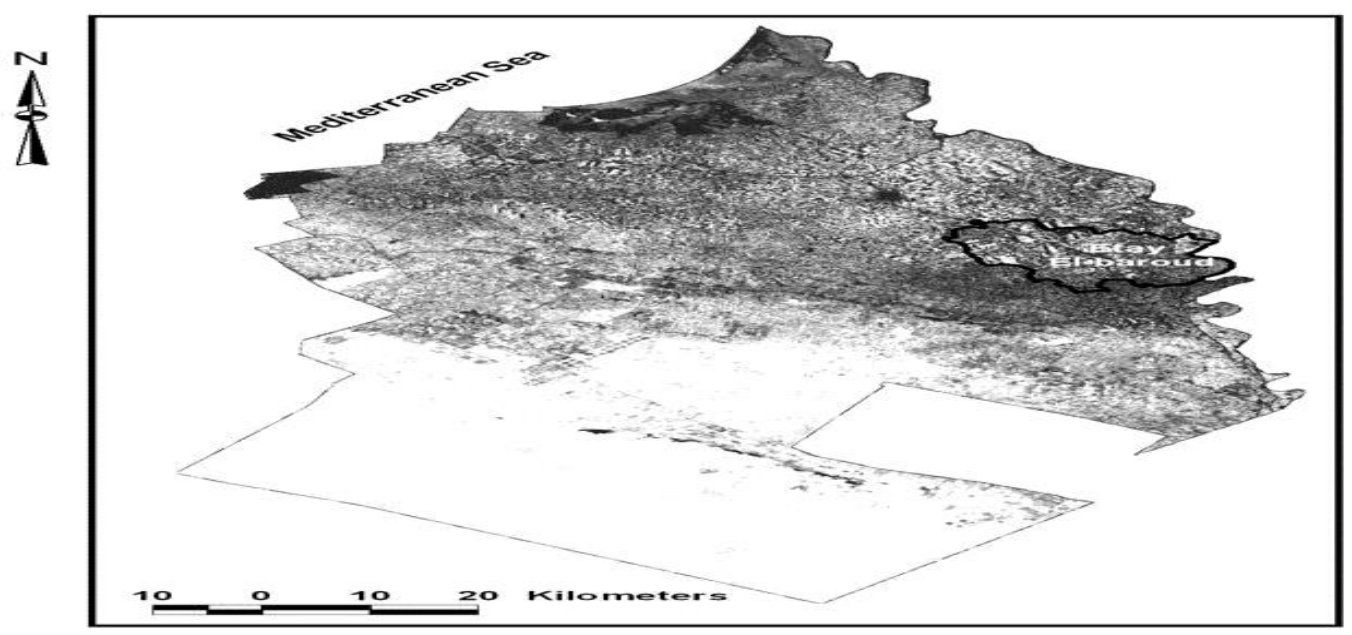

Figure 1. Satellite image of Etay El-Baroud district in Behira Governorate. (c) M. Bahnassy reprinted with permission. Grey color indicates the distribution of cultivated lands within the whole Governorate. The image is showing that the study area represents a typical agricultural area and leaching of agricultural chemicals to subsurface shallow groundwater is highly potential.

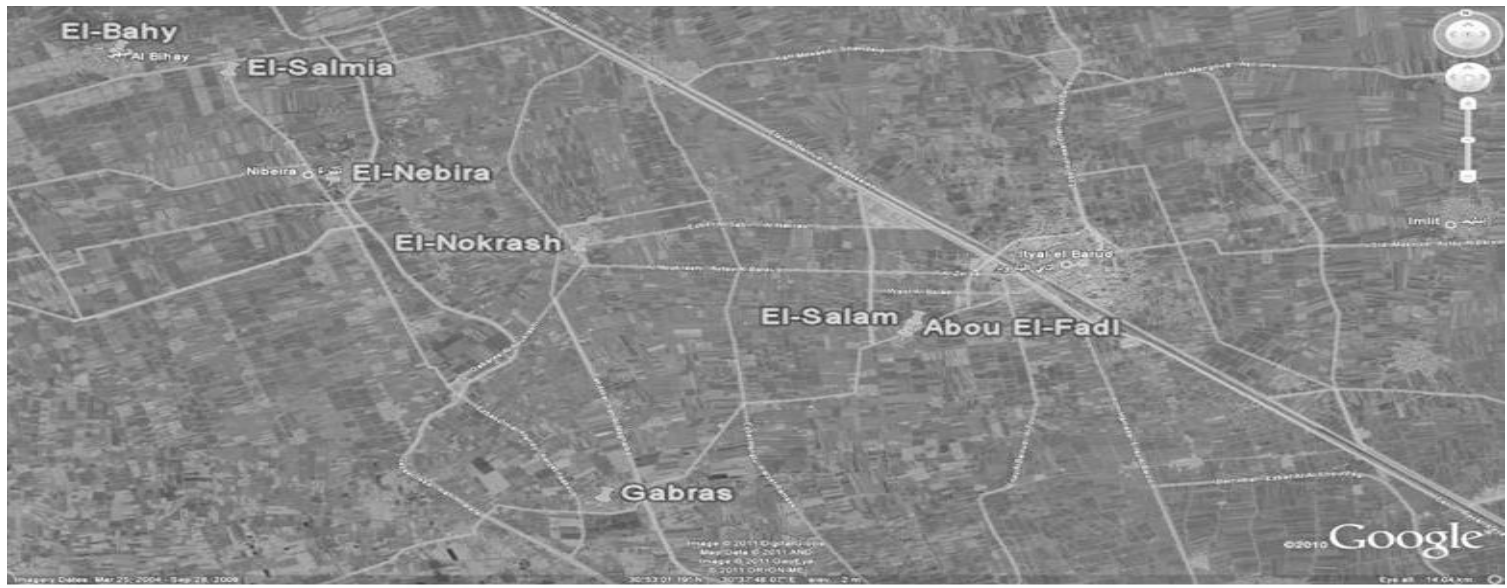

Figure 2. Google Earth map showing the studied villages and sampling sites in Etay El-Baroud district, Behira Governorate, Egypt 


\section{DISCUSSION}

Egypt; like almost all countries of the Mediterranean Region, lacks a clear strategy for setting, promulgation and review of drinking-water quality standards. Issued standards have been adapted from World Health Organization (WHO) and international standards of other agencies and Egyptian epidemiological studies that may help realize a more rational adaptation and determination of standards are virtually non-existent.(23) The Decree of the Egyptian Ministry of Health No. 108 and $301 / 1995$ have stated the quality standards of drinking-water in Egypt which identified the maximum residue limit (MRL) for chemicals of health significance. Such limits are available for only 8 chemicals and in most cases their values are typical those of WHO except for carbofuran $(0.005$ ppm) and DDT and metabolites (0.002 ppm). The permissible limits of OCs in drinking water as stated by $\mathrm{WHO},{ }^{(24)}$ are 1 ppb for DDT, 0.03 ppb for aldrin/dieldrin, heptachlor and heptachlor epoxide, and $2 \mathrm{ppb}$ for lindane. Thus, according to $\mathrm{WHO}$ and Egyptian standards, total drins, heptachlor and heptachlor-epoxide exceed the limit, while total DDT and lindane residues are within the range. Moreover, European Drinking Water Directive (EU) suggested that, pesticides can be expected in shallow groundwater at low concentrations (below $0.1 \mathrm{ppb}$ ) and no pesticide is allowed at a concentration above this limit.(25) Accordingly, total drins, heptachlor, total DDT content in our samples have exceeded the set limit, while lindane and malathion are on the borders. Following Environmental Protection Agency (EPA) drinking water standards and health advisories,(26) most detected residues in groundwater samples were below the maximum residue limits (MRL) values of EPA; nevertheless, their health advisories and cancer risk imposed on people over long-term exposure are alarming.

Elevated concentrations in water are likely 
to indicate point source pollution rather than normal agricultural use. Common activities producing such pollution may include amenity use of general weed killers and poor practice in pesticide storage or disposal of pesticide spray tanks. As indicated by the survey questionnaire, a close proximity of hand pumps to fields was highly noticed where $66 \%$ of households were at a distance $<20 \mathrm{~m}$, and as such were most likely located very close to agricultural drainage $(62 \%)$ which makes the seepage of contaminants to shallow groundwater more likely.

Detectable amounts of $\mathrm{OC}$ pesticides in water may be due to continuous degradation of DDT and $\mathrm{HCH}$ into their metabolites and isomers and such amounts found their way to the subsurface water through penetration of the soil. Furthermore, it is worth mentioning that our analysis identified 5 kinds of pesticides that were mentioned by farmers. The remaining compounds were either detected once in some samples or detected at very low insignificant concentrations. This may be due to the fact that some residues can be rapidly decomposed in the environment and consequently did not appear in the analysis. Moreover, no residue analysis can detect all types of residues present in a given sample.

Worldwide, several pesticide residues have been detected in the groundwater, such as the occurrence of atrazine in groundwater of several states of Canada, (27) atrazine/nitrates/2,4-D in Cortland County, New York, (28) chlorpyrifos, dieldrin, DDT, 2,4-D in Minnesota,(29) and endosulfan and chlorpyrifos in South Africa. ${ }^{(30)}$ Additionally, our results are consistent with previous survey findings conducted in other areas of the same governorate, where subsurface water samples were found to be contaminated with residues of heptachlor, dieldrin, $\mathrm{DDT}$ and its metabolites, $\mathrm{HCH}$ isomers and aldrin in high concentrations. ${ }^{(31)}$ Likewise, current results 
also support the findings of previous investigations reporting pesticide residues in surface and groundwater as a result of chemical control of cotton pests in Egypt.(32)

Moreover, Soil samples collected from three other governorates in Egypt were previously proved to contain residues of lindane, chlordane and DDT metabolites. (33) Leaching of agricultural pesticides to shallow groundwater in highly vulnerable aquifers can be a hazard, and the potential persistence of toxic compounds in these systems is a real risk. ${ }^{(34)}$

As for dust samples, pyrethroid compounds represented the highest residues detected in indoor dust samples, where their levels were $4.75,2.69,15.21$ $\mathrm{ug} / \mathrm{ml}$ (ppm) for permethrin, cypermethrin, and cyahalothrin, respectively. This can be attributed to the heavy use of spray formulations against houseflies and mosquitoes with no adequate aeration.
Besides, DDT, $\mathrm{HCH}$, and endosulfan were found in most samples at concentrations of 10.42, 36.01, and $33.68 \mathrm{ppb}$; respectively. Though there are no comparable studies regarding pesticide levels in house dust recorded in Egypt, other studies worldwide indicated a three-fold difference in median chlorpyrifos house dust concentration between farm workers who did not directly handle pesticides and reference families. ${ }^{(35)}$ Exposure to diazinon in house dust in California's children could exceed the EPA oral reference dose of $9.0 \mathrm{E}-05$ mg. $\mathrm{kg}^{-1}$ day $^{-1}{ }^{(36)}$ and contamination in the homes of farm families are likely to be higher than that in other homes where significant sources of exposure to farm worker families may be derived from their residential proximity to fields. In lowa and North Carolina, between 40 and $50 \%$ of families' homes were located within 100 yards of crop fields inducing higher levels of pesticides in house dust associated with risks among residents. ${ }^{(35)}$ and when 
compared to the herbicide levels detected

in non-farm homes, farmhouses had significantly greater frequency of detection and elevated concentrations in dust.(37) Numerous pesticides are known to penetrate the skin, so exposures from pesticides on hands would be both oral and dermal. Actually, hands moist with saliva collect more pesticide residues than dry hands. ${ }^{(38)}$

Based on our field questionnaire, oneon-one interviews of community members, their own medical histories and their personal believes; water-related diseases were common among villagers and most of them were found to believe highly in causal relation between environmental problems and their health status. The percentage of sick family members was relatively high among children and women, where frequency of disease prevalence among children was (36\%) followed by women (28\%), elders (21\%), and men (14\%). Affliction of all age groups by water-related diseases particularly diarrhea, infectious hepatitis, kidney failure and others, may reflect their exposure to many pathogens and contaminants in groundwater and/or other environmental media which negatively affect the general health status. The link between the detected pesticides, possible exposure pathways and the current health status of the respondents is difficult to be established in the current study since the gathered health information are descriptive and other detailed criteria are needed to establish such link. However, in Egypt, exposure to organophosphorus and carbamate pesticides in different media may lead to symptoms of pesticide intoxication like vomiting and diarrhea, ${ }^{(11)}$ and contribute as additive risk factors to current hepatitis B and $\mathrm{C}$ viruses infection among rural males. ${ }^{(39)}$ The health hazards posed by pesticide exposure on children are expected since they may come into contact with pesticide residues through agricultural 
employment, pesticide drift, contaminated groundwater, or soil.

Thus, there are many health risks/hazards that may adversely affect the studied community health through different types of exposure. Age, living in close proximity to agricultural fields, excessive use of pesticides indoors without adequate aeration, lack of awareness and poor water quality, represented the major risk factors. Thus, environmental risk management strategies at different levels must be taken into consideration. At home, minimized use of pesticides, use of non-chemical pest control methods, storing pesticides in containers with child-proof seals and out of reach, continuous cleaning processes for indoor surfaces and carpets to avoid contact with contaminated fine dust, should be considered. At the community level, there is an urgent need for promoting community environmental awareness campaigns, school activities, use of protective measures, pesticide-free "zones" and it is important that communities promote organic farming practices in their areas. Moreover, it is advisable that farmers' housings should be located far away from cropping fields. Finally, it is imperative that trained or licensed pesticide applicators are the only permitted to use pesticide to reduce community risks to pesticide hazards.

\section{CONCULSION}

The examined shallow groundwater and indoor dust samples failed to meet the regulatory MRLs in many cases. Pesticide residues were detected in both media and data indicated vulnerability of shallow groundwater and higher contamination of indoor dust particularly with pyrethroid compounds. More exposure/risk assessment studies related to the Egyptian settings are necessary to enhance drinking water regulations and lower pesticide exposure. Also, the fact that agricultural pesticides can be brought into the home, accumulate in carpet dust, and end up on 
children's hands should be considered

when evaluating cumulative exposure to and risk of pesticides, even for those not registered for household use.

\section{REFERENCES}

1. World Health Organization. Public Health Impact of Pesticides Used in Agriculture. Geneva: WHO; 1990. 79-82.

2. Plimmer JR. Dissipation of pesticides in the environment. In: Schnoor, JL [ed.], Fate of pesticides and chemicals in the environment. New York: Wiley; 1991. 7991.

3. Bass AM. What's being used at home: A household pesticide survey? Pan Am. J. Pub. Health. 2001; 9: 13-21.

4. Nishioka MG, Burkholder HM, Brinkman MC. Measured transport of lawn-applied herbicide acids from Turf to home: Correlation of dislodgeable 2,4-D Turf residues with carpet dust and carpet surface residues. Environ. Sci. \& Tech. 1996b; 30: 3313-3320.

5. Wallace JC, Brzuzy LP, Simonich SL, Visscher SM, Hites RA. A Case study of organochlorine pesticides in the indoor air of a home. Environ. Sci. \& Tech. 1996; 30: 2715-2718.

6. Lewis RG, Fortmann RC, Camann DE. Evaluation of methods for monitoring the potential exposure of small children to pesticides in the residential environment. Arch. Environ. Contam. \& Toxicol. 1994; 26: 37-46.

7. Roberts JW. Reducing dust, lead, dust mites, bacteria, and fungi in carpets by vacuuming. Arch. Environ. Contam. \& Toxicol. 1999; 36: 477-484.

8. Calabrese EJ, Stanek EJ. What proportion of household dust is derived from outdoor soil?. J. Soil Contam. 1992; 1: 253-263.
9. Camann DE, Harding $\mathrm{H}$, Lewis $\mathrm{R}$. Trapping of particle-associated pesticides in indoor air by polyurethane foam and exploration of soil track-in as a pesticide source. Proceedings of the 5th International Conference on Indoor Air Quality and Climate. Toronto; 1990. 90-97.

10. Mansour SA. Pesticide exposure-Egyptian scene. Toxicol. 2004; 198(1-3):91-115.

11. Mansour SA. Environmental impact of pesticides in Egypt. Rev. Environ. Contam. Toxicol. 2008; 196: 1-51.

12. Groundwater Foundation. Sources of groundwater contamination.[Internet] 2007; [cited year month day]. Available from: http:// www. groundwater. org/gi/sourcesofgwcontam.html.

13. Shams El-Din AN, Seleim ZM, ElMousallamy A, Abdel-Gawad AA. Monitoring of pesticide residues in drinking water. J. Egy. Soc. Toxicol. 1996; 16:111114.

14. Abdallah SM, Gaber HM. Monitoring of pesticide residues in different sources of drinking water in some rural areas. Alex. J. Agri. Res. Sci. 2003; 48(3): 187-199.

15. Human Rights Watch. Underage and Unprotected: Child labor in Egypt's cotton fields. UNHCR (The UN Refugee Agency). 2001, $\quad \mathrm{http} / \mathrm{wwww}$.unhcr.org/refworld/ topic, 459 d17822.html

16. STM-APHA. (1998) Standard methods for examining of water and wastewater. 20th edition. Washington DC: American Public Health Association; 1998.123-146.

17. Camann DE, Harding HJ, Geno PW. Relationship among drag sled, PUF roller, and hand press transfer of pesticide residues from floors. In: Measurement of Toxic Air Pollutants, Proceedings of USEPA/ADWMA International Conference. Durham, North Carolina; 1994. 197-202.

18. Balinova AM. Analysis of fenoxaprop-ethyl and fenoxaprop in drinking water using solid-phase extraction and ion-pair HPLC. Pest. Sci. 1996; 48: 219-223. 
19. USEPA. Manual of Analytical Quality Control for Pesticides in Human and Environmental Media. Research Triangle Park, N.C 27711; 1982.

20. ISO/IEC. EN 45001, Guide 25, General Requirements for the Competence of Calibration and Testing laboratories, Geneva; 1990.

21. Gomez KA, Gomez, KH, Gomez AA. Statistical Procedures for Agricultural Research. 2nd edition. New York: John Willy and Sans Press; 1984.

22. SAS Release 6.12. SAS for Windows. SAS Institute: Cary, NC; 1989-1996.

23. World Health Organization.

Compendium of Drinking-Water Quality Standards in the Eastern Mediterranean Region (2006). World Health Organization, Regional Office for the Eastern Mediterranean, Regional Center for Environmental Health Activities, CEHA. WHO-EM/CEH/143/E.

24. World Health Organization. Guidelines for drinking water quality. 3rd edition Vol. 1, Geneva; 2004.

25. Scheuer S. European Regulation, EU Groundwater Protection at Risk. Pesticides News 73. European Environmental Bureau; [Internet] 2006; [cited year month day]. Available from: http://www.PanUK.org/pestnews/lssue/pn73/pn73p8.pdf

26. USEPA. Edition of the Drinking Water Standards and Health Advisories. US Environmental Protection Agency, Office of Water. Washington, DC: EPA 822-R-06013; 2006.

27. Eason A, Tim U, Wang X. Integrated modeling environment for statewide assessment of groundwater vulnerability from pesticide use in agriculture. GIS/EM4 No.182. 4th International Conference on Integrating GIS and Environmental Modeling (GIS/EM4): Problems, Prospects and Research Needs. Banff, Alberta, Canada. September, 2-8; 2000.

28. Sinkevich MG, Walter MT, Lembo AJ, Richards BK, Peranginangin N, Aburine
SA, et al. A GIS-based groundwater contamination risk assessment tool for pesticides. Groundwater Monit \& Remed. 2005; 25(4):82-91.

29. MDH; Minnesota Department of Health. Comparative risks of multiple chemical exposures. Final Report for Legislative Commission on Minnesota Resources; 2000.

30. Dalvie MA, Cairncross E, Solomon A, London L. Contamination of rural surface and groundwater by endosulfan in farming areas of the Western Cape. South Africa Environ. Health 2003; 10(2):1-12.

31. Youssef SH, Samaan MA, El-Shemy $\mathrm{MKH}$. Monitoring pesticide residues in canals, bore holds and tap water during chemical control of cotton pest in Egypt. Egy. J. Appl. Sci. 1992; 7(7): 171-80.

32. Tchounwou PB, Ashour BA, MorelandYoung C, Ragheb DA, Romeh AA, Goma $E$, El-Sheikh $S$, et al. Health risk assessment of pesticide usage in Menia El-Kamh province of Sharkia Governorate in Egypt. Int. J. Mol. Sci. 2002; 3:10821094.

33. Aly OA, Badawy MI. Organochlorine insecticides in selected agricultural areas in Egypt. In: Proceedings of the International Symposium on Managing Industrial Wastewater in Developing Nations. Alexandria, Egypt. 28-31 March; 1981; 273-281.

34. Morris BL, Lawrence ARL, Chilton PJC, Adams B, Calow RC, Klinck BA. Groundwater and Its Susceptibility to Degradation: A Global Assessment of the Problem and Options for Management. Early warning and assessment. United Nations Environment Program. Report Series: Rs.03-3. Nairobi, Kenya; 2003.

35. Simcox NJ, Fenske RA, Wolz SA, Lee IC, Kalman DA. Pesticides in household dust and soil: Exposure pathways for children of agricultural families. Environ. Health Perspect. 1995; 103: 1126-1134. 
36. Bradman MA, Harnly ME, Draper W, Seidel S, Teran S, Wakeham D, et al. Pesticide exposures to children from California's Central Valley: Results of a pilot study. J. Exp. \& Anal. Environ. Epidemiol. 1997; 7: 217-234.

37. Camann DE, Akland GG, Buckley JD, Bond $\mathrm{AE}$, Mage DT. Carpet dust and pesticide exposure of farm children. International Society of Exposure \& Analysis, Annual Meeting. Research
Triangle Park, NC; 1997.

38. Camann DE, Majumdar TK, Harding HJ, Ellenson WD, Lewis RG. Transfer efficiency of pesticides from carpet to saliva-moistened hands. Measur. Tox. \& Rel. Air Poll. 1996; 64:532-540.

39. Ezzat S, Abdel-Hamid M, Eissa SA, Mokhtar N, Labib NA, El-Ghorory L, et al. Association of pesticides, HCV,HBV, and hepatocellular carcinoma in Egypt. Int. J. Hyg. Environ. Health 2005; 208(5): 329339. 